\title{
Genetic diversity of tambaqui broodstocks in stock enhancement programs
}

\section{Diversidade genética de estoques de reprodutores de tambaqui utilizados em programas de repovoamento}

\author{
Américo Moraes Neto ${ }^{1}$; Denise Rocha Ayres²; Danilo Pedro Streit Junior ${ }^{3}$; \\ Nelson Mauricio Lopera-Barrero ${ }^{4}$; Paulo Bahiense Ferraz Filho; ${ }^{5}$ Ruy Alberto \\ Caetano Corrêa Filho5; Annaiza Braga Bignardi²; Caroline Michele Marinho \\ Marciano ${ }^{6}$; Pâmela Juliana Furlan Murari ${ }^{7}$; Jayme Aparecido Povh ${ }^{5^{*}}$
}

\begin{abstract}
Natural populations of tambaqui (Colossoma macropomum) have significantly decreased in recent decades especially due to human extraction activities. So that the environmental impact may be reduced, the restocking of fish and increase in fish production are enhanced. Genetic evaluations using molecular markers are essential for this purpose. Current study evaluates the genetic variability of two tambaqui broodstocks used in restocking programs. Sixty-five samples (33 samples from broodstock A and 32 samples from broodstock B) were collected. DNA was extracted from caudal fin samples, with the amplification of four microsatellite loci: Cm1A11 (EU685307) Cm1C8 (EU685308) Cm1F4 (EU685311) and Cm1H8 (EU685315). Fourteen alleles in the stock of broodstock A were produced, five alleles for Cm1A11 locus (230, 255, 260, 270 and 276 bp), three alleles Cm1C8 (239, 260, and $273 \mathrm{bp}$ ), two alleles Cm1F4 (211 and $245 \mathrm{bp}$ ), four alleles for Cm1H8 (275, 290, 320 and $331 \mathrm{bp}$ ) and two unique alleles were found for Cm1A11 loci (alleles 270 and 276 bp) and Cm1H8 (alleles 275 and $331 \mathrm{bp}$ ). In broodstock B, ten alleles were produced, the same alleles of the first stock except for alleles 270 and 276 bp in Cm1A11 locus and 275 and 331 bp in Cm1H8 locus. Broodstock A revealed low frequency alleles in $\mathrm{Cm} 1 \mathrm{~A} 11$ loci, $\mathrm{Cm} 1 \mathrm{C} 8, \mathrm{Cm} 1 \mathrm{~F} 4$ and $\mathrm{Cm} 1 \mathrm{H} 8$, whereas broodstock $\mathrm{B}$ had no locus with low allelic frequency. Loci $\mathrm{Cm} 1 \mathrm{~A} 11, \mathrm{Cm} 1 \mathrm{C} 8$ and $\mathrm{Cm} 1 \mathrm{H} 8$ exhibited significant deficit of heterozygotes in both broodstocks, revealing changes in Hardy-Weinberg equilibrium. Genetic diversity between stocks was 0.1120 , whilst genetic similarity was 0.894 , with $\mathrm{F}_{\mathrm{ST}}$ rate $=0.05$, and $\mathrm{Nm}=3.93$, indicating gene flow between the two broodstocks. Results show that broodstocks are genetically closely related, with no great genetic variability. Strategies such as a previous genetic analysis of breeding with its marking, use of a large Ne crossing between the most genetically divergent specimens, and the introduction of new genetic material to broodstocks may maximize genetic diversity and minimize inbreeding within the next generation.
\end{abstract}

Key words: Colossoma macropomum. Genetics conservation. Molecular markers. Microsatellite.

\footnotetext{
${ }^{1}$ Discente do Curso de Doutorado, Programa de Pós-Graduação em Ciência Animal, Universidade Federal de Mato Grosso do Sul, UFMS, Faculdade de Medicina Veterinária e Zootecnia, Campo Grande, MS, Brasil. E-mail: netoamerico@gmail.com

2 Prof ${ }^{\text {as }}$ Dr ${ }^{\text {as }}$, Departamento de Zootecnia, Universidade Federal de Mato Grosso, UFMT, Rondonópolis, MT, Brasil. E-mail: derocay@gmail.com; annaizabb@gmail.com

${ }^{3}$ Prof. Dr., Faculdade de Agronomia, Universidade Federal do Rio Grande do Sul, UFRGS, Porto Alegre, RS, Brasil. E-mail: danilo.streit@ufrgs.br

${ }^{4}$ Prof. Dr., Departamento de Zootecnia, Universidade Estadual de Londrina, UEL, Londrina, PR, Brasil. E-mail: nmlopera@uel.br

5 Prof. Dr., Faculdade de Medicina Veterinária e Zootecnia, UFMS, Campo Grande, MS, Brasil. E-mail: paulo.ferraz@ufms.br; ruy.filho@ufms.br; jayme.peixegen@gmail.com

${ }^{6}$ Discente do Curso de Graduação em Zootecnia, UFMT, Rondonópolis, MT, Brasil. E-mail: marinho.cmm@gmail.com

${ }^{7}$ Discente do Curso de Doutorado, Programa de Pós-Graduação em Ciência Animal, UEL, Londrina, PR, Brasil. E-mail: pamela. furlan@outlook.com

* Author for correspondence
} 


\section{Resumo}

A população natural do tambaqui (Colossoma macropomum) está reduzindo significativamente nas últimas décadas devido às ações antrópicas, como o extrativismo. Para diminuir este impacto ambiental, o repovoamento de peixes e aumento da produção piscícola estão sendo realizados. Para tanto, avaliações genéticas por meio de marcadores moleculares são fundamentais. Desta forma, o objetivo deste trabalho foi avaliar a variabilidade genética de dois estoques de reprodutores de tambaqui utilizados em programas de repovoamento. Foram coletadas 65 amostras (33 amostras do estoque A e 32 amostras do estoque B). O DNA foi extraído de amostras da nadadeira caudal, com a amplificação de quatro loci microssatélite: Cm1A11 (EU685307), Cm1C8 (EU685308), Cm1F4 (EU685311) e Cm1H8 (EU685315). Foram produzidos 14 alelos no estoque de reprodutores A, cinco alelos para o locus $\mathrm{Cm} 1 \mathrm{~A} 11$ (230, 255, 260, 270 e $276 \mathrm{pb}$ ), três alelos para Cm1C8 (239, 260 e $273 \mathrm{pb})$, dois alelos para Cm1F4 (211 e $245 \mathrm{pb})$, quatro alelos para $\mathrm{Cm} 1 \mathrm{H} 8(275,290,320$ e $331 \mathrm{pb})$ e dois alelos exclusivos foram encontrados para os loci Cm1A11 (alelos 270 e 276 pb) e Cm1H8 (alelos 275 e $331 \mathrm{pb}$ ). Para o estoque de reprodutores $\mathrm{B}$ foram produzidos 10 alelos, os mesmos alelos do primeiro estoque, exceto para os alelos 270 e $276 \mathrm{pb}$ no locus Cm1A11 e 275 e 331 pb no locus $\mathrm{Cm} 1 \mathrm{H} 8$. No estoque de reprodutores A foi observado alelos de baixa frequência nos loci $\mathrm{Cm} 1 \mathrm{~A} 11, \mathrm{Cm} 1 \mathrm{C} 8, \mathrm{Cm} 1 \mathrm{~F} 4$ e Cm1H8. Já o estoque de reprodutores B não apresentou locus com baixa frequência alélica. Os loci Cm1A11, Cm1C8 e Cm1H8 exibiram significativo défict de heterozigotos em ambos os estoques de reprodutores, indicando alteração no equilíbrio de Hardy-Weinberg. A divergência genética foi de 0,1120 entre os estoques, enquanto a similaridade genética foi de 0,894 , com o valor de $F_{S T}$ igual a 0,05 , e o $\mathrm{Nm}$ igual a 3,93 indicando fluxo gênico entre os dois estoques de reprodutores. Os resultados obtidos revelam que os estoques de reprodutores estão geneticamente muito relacionados e que ambos os estoques não apresentam alta variabilidade genética. Estratégias como uma prévia análise genética dos reprodutores com sua marcação, utilização de um grande $N_{e}$, cruzamento entre indivíduos geneticamente mais divergentes, além da introdução de um novo material genético aos estoques de reprodutores, poderiam ser utilizadas para maximizar a variabilidade genética e minimizar a endogamia na próxima geração.

Palavras-chave: Colossoma macropomum. Conservação genética. Marcadores moleculares. Microssatélite.

Brazil has the biggest fish diversity on the continent, extensive available fresh water and a favorable climate for aquiculture, coupled to being a great producer of inputs for aquaculture. All these factors reveal the country's significant aquaculture capacity (LOPERA-BARRERO et al., 2011). However, extractivism is the main cause that triggered a sharp decrease in natural stocks. In fact, extractivism has greatly diminished the natural population of Colossoma macropomum (locally called tambaqui) during the last decades, due to human activities (THOMÉ-SOUZA et al., 2007). Several strategies have been deployed to mitigate the environmental impact, among which may be mentioned fish restocking and increase in fish production. These events have made fish genetic studies highly necessary while molecular markers have proved to be useful for this end (JACOMENTO et al., 2010; LOPERA-BARRERO et al., 2015;
POVH et al., 2011; RODRIGUEZ-RODRIGUEZ et al., 2010). There is a lack of information on the genetic assessment of stock enhancement programs for the tambaqui.

Sixty-five samples from the caudal fin were collected from two stocks of tambaqui broodstocks in a commercial fish culture in the municipality of Pimenta Bueno RO, north Brazil (1141'46”S; $\left.61^{\circ} 13^{\prime} 47^{\prime \prime} \mathrm{W}\right)$, namely, 33 samples from broodstock A and 32 samples from broodstock B.

DNA was extracted from the caudal fins following protocol by Lopera-Barrero et al. (2008). Loci Cm1A11 (EU685307), Cm1C8 (EU685308), Cm1F4 (EU685311) and Cm1H8 (EU685315) were amplified by primers following methodology described by Santos et al. (2009). Reactions were amplified in Eppendorf Mastercycler Gradient thermocycler. 
Amplified samples underwent polyacrylamide gel electrophoresis 10\%, de-naturant (6 M urea), for 12 hours at $15 \mathrm{~mA}$. Protocol by Bassam et al. (1991) was employed to visualize the alleles and fragment size was estimated by comparison with standard ladder 10, 50 and $100 \mathrm{bp}$ (Invitrogen).

Observed heterozygosity $\left(H_{O}\right)$, expected heterozygosity $\left(H_{E}\right)$, the number of migrants $(\mathrm{Nm})$, the coefficient of endogamy $\left(F_{I S}\right)$ and HardyWeinberg's equilibrium test (PHW) were analyzed by statistical program GENEPOP 1.2 (RAYMOND; ROUSSET, 1995). Genetic differentiation rates $\left(F_{S T}\right)$ were calculated by FSTAT 2.9.3.2 (GOUDET, 2002) and the genetic distance and similarity by program POPGENE 1.31 (YEH et al., 1999).

The stock of broodstocks A and B had 14 and 10 alleles respectively. The stocks of broodstock A featured five alleles for locus Cm1A11 (230, 255, 260, 270 and $276 \mathrm{bp}$ ), three alleles for Cm1C8 (239, 260 and $273 \mathrm{bp}$ ), two alleles for Cm1F4 (211 and $245 \mathrm{bp})$ and four alleles for Cm1H8 $(275,290,320$ and $331 \mathrm{pb}$ ). Two exclusive alleles in this stock of broodstocks were reported for loci Cm1A11 (alleles 270 and 276 bp) and Cm1H8 (alleles 275 and 331 $\mathrm{bp}$ ). The stocks of broodstock B comprised the same alleles of the former stock with the exception of alleles 270 and 276 bp in locus Cm1A11 and 275 and $331 \mathrm{bb}$ in locus $\mathrm{Cm} 1 \mathrm{H} 8$. This fact reveals a smaller genetic variability in the stock.

The number of alleles in the two stocks of broodstocks was lower than that reported by Santos et al. (2009) who registered between 13 and 21 alleles for the same loci in a sample of 25 specimens of a wild tambaqui population. Data demonstrate that the two stocks of broodstocks did not have a great genetic variability between them.

There was a low frequency $(<0.1)$ of alleles in loci Cm1A11 (allele $270 \mathrm{bp}=0.0667$ and allele $276 \mathrm{bp}=0.0667), \mathrm{Cm} 1 \mathrm{C} 8$ (allele $273 \mathrm{bp}=0.0645$ ), Cm1F4 (allele $211 \mathrm{bp}=0.0962$ ), Cm1H8 (allele $331 \mathrm{bp}=0.0962)$ in the stock of broodstock A. On the other hand, the stock of broodstock B failed to provide alleles in these conditions. Further, only one of the absent alleles in the stock of broodstock $\mathrm{B}$ did not feature low frequency in the stock of broodstocks A (allele 275 bp of locus Cm1H8 = 0.1923).

Alleles may be eliminated throughout generations due to factors involving selection (intentional or not) and effective number of broodstocks (POVH et al., 2011). Low frequency alleles in the stock of broodstocks A may be eliminated in the next generations due to adopted reproduction management. These factors are still active in the two stocks of broodstocks since three out of four exclusive alleles of the stock of broodstock A have low frequency.

The absence of four alleles in the stock of broodstock B may be related to the founding effect in their formation. Since the stock of broodstocks B did not have any low frequency allele, an equilibrium in the genetic variability of the two stocks of broodstocks may be suggested due to the alleles' number and frequency.

Loci $\mathrm{Cm} 1 \mathrm{~A} 11, \mathrm{Cm} 1 \mathrm{C} 8$ and $\mathrm{Cm} 1 \mathrm{H} 8$ revealed a significant deficiency of heterozygotes (PHW) in the two stocks of broodstocks (Table 1). Similarly, mean number of loci had the same behavior. Since excess of heterozygotes in locus Cm1F4 was not significant, both stocks were within the HardyWeinberg equilibrium for the locus. Analysis of the other loci and mean loci reveal that both stocks of broodstocks fail to demonstrate equilibrium since mean observed heterozygosity (Ho) was smaller than expected heterozygosity $\left(H_{E}\right)$. However, high $H_{O}$ rates indicate a greater genetic variability in the stock of broodstocks A.

Changes in Hardy-Weinberg equilibrium with heterozygote deficit suggests that endogamy may be occurring within the two stocks of broodstocks, preponderantly in the stock of broodstock B. Depending on the adopted reproduction management, the situation may occur in fish cultures mainly because of mating between kin fish, small $N_{e}$ and founding effect (LOPERA-BARRERO et al., 2015; RODRIGUEZ-RODRIGUEZ et al., 2010). 
Table 1. Observed heterozygosis $\left(H_{O}\right)$, expected Heterozygosis $\left(H_{E}\right)$, Coefficient of endogamy $\left(F_{I S}\right)$ and HardyWeinberg equilibrium test (PHW) of microsatellite loci for two stocks of tambaqui broodstocks.

\begin{tabular}{|c|c|c|c|c|c|}
\hline Stock & Locus & $\boldsymbol{H}_{0}$ & $\boldsymbol{H}_{E}$ & $F_{I S}$ & PHW \\
\hline \multirow{5}{*}{$\mathbf{A}$} & Cm1A11 & 0.5667 & 0.7452 & 0.2267 & $* *$ \\
\hline & Cm1C8 & 0.2903 & 0.4638 & 0.3637 & $* *$ \\
\hline & Cm1F4 & 0.1923 & 0.1772 & -0.1064 & ns \\
\hline & Cm1H8 & 0.3846 & 0.6916 & 0.4329 & $* *$ \\
\hline & Mean & 0.3585 & 0.5194 & 0.2292 & $* *$ \\
\hline \multirow{5}{*}{ B } & Cm1A11 & 0.4 & 0.5316 & 0.2349 & $* *$ \\
\hline & $\mathrm{Cm} 1 \mathrm{C} 8$ & 0.2188 & 0.4856 & 0.5424 & $* *$ \\
\hline & Cm1F4 & 0.3226 & 0.275 & -0.1923 & ns \\
\hline & Cm1H8 & 0.0741 & 0.3913 & 0.8071 & $* *$ \\
\hline & Mean & 0.2539 & 0.4209 & 0.348 & $* *$ \\
\hline
\end{tabular}

Genetic divergence reached 0.1120 between the stocks, whereas genetic similarity featured 0,894 . Results reveal that the stocks of broodstocks are genetically highly related. They are corroborated by $F_{S T}=0.05$, which indicates low genetic difference, according to Wright (1978). $\mathrm{Nm}=3.93$ indicate a genic flow between the two stocks of broodstocks, corroborating the above.

Induced reproduction of the tambaqui among kin specimens is not common due to the fish's high fecundity (GALO et al., 2015). Increase in endogamy may eliminate important allele combinations such as those related to pathogen resistance and adaptability. Further, endogamy may be an asset to the manifestation of lethal genes or those related to deformities or other genetic problems that jeopardize offspring feasibility.

In the case of the founding effect, it may be beneficent or maleficent during broodstock formation. When it is beneficent, the founding effect may provide a good genetic constitution for broodstocks, good genetic variability and low endogamy level in the following generations, if reproduction management is adapted. Contrastingly, if the founding effect defined an initial bad genetic constitution for broodstocks, the problems related to low genetic variability and high endogamy are prone to emerge in the next generations.

Results demonstrate that the two stocks of broodstocks do not have high genetic variability. Further, the two stocks are genetically very similar. Early genetic analysis of broodstock, marking of broodstocks, the employment of a high $N_{e}$ and in-breeding between genetically more divergent specimens are highly relevant to maximize genetic variability and minimize endogamy in the next generation. The introduction of new genetic matter plus new genotypes to the stocks of broodstocks may also be employed for the same purpose.

\section{References}

BASSAM, B. J.; CAETANO-ANOLLÉS, G.; GRESSHOFF, P. M. Fast and sensitive silver staining of DNA in polyacrylamide gels. Analytical Biochemistry, New York, v. 196, n. 1, p. 80-83, 1991. 
GALO, J. M.; RIBEIRO, R. P. B.; STREIT JUNIOR, D. P.; ALBUQUERQUE, D. M.; FORNARI, D. C.; ROMA, C. F. C.; GUERREIRO, L. R. J. Oocyte quality of Tambaqui (Colossoma macropomum) during the reproductive season. Braziliam Journal of Biology, São Carlos, v. 75, n. 2, p. 279-284, 2015.

GOUDET, J. FSTAT: a program to estimate and test gene diversities and fixation indices (version 2.9.3.2). Lausanne: University of Lausanne, Department of Ecology \& Evolution, 2002. Available at: <http://www2. unil.ch/popgen/softwares/fstat.htm>. Accessed at: 20 may 2016.

JACOMENTO, C. B.; LOPERA BARRERO, N. M.; RODRIGUEZ-RODRIGUEZ, M. D. P.; GOMES, P. C.; POVH, J. A.; STREIT JUNIOR, D. P.; VARGAS, L.; RESENTE, E. K.; RIBEIRO, R. P. Variabilidade genética em tambaquis (Teleostei: Characidae) de diferentes regiões do Brasil. Pesquisa Agropecuária Brasiliera, Brasília, v. 45, n. 5, p. 481-487, 2010.

LOPERA-BARRERO, N. M.; POVH, J. A.; RIBEIRO, R. P.; GOMES, P. C.; JACOMETO, C. B.; LOPES, T. S. Comparación de protocolos de extracción de ADN con muestras de aleta y larva de peces: extracción modificada con cloruro de sodio. Ciencia e Investigación Agraria, Santiago, v. 35, n. 1, p. 77-86, 2008.

LOPERA-BARRERO, N. M.; RIBEIRO, R. P.; POVH, J. A.; MENDEZ, L. V.; POVEDA-PARRA, A. R. Produção de organismos aquáticos: uma visão geral no Brasil e no mundo. Guaíba: Agrolivros, 2011. 320 p.

LOPERA-BARRERO, N. M.; RODRIGUEZRODRIGUEZ, M. D. P.; FORNARI, D. C.; RESENDE, E. K.; POVEDA-PARRA, A. R.; BRACCINI, G. L.; SOUZA, F. P.; FURLAN, P. J.; POVH, J. A.; RIBEIRO, R. P. Genetic variability of broodstocks of Tambaqui (Teleostei: Characidae) from the northeast region of Brazil. Semina. Ciências Agrárias, Londrina, v. 36, n. 6, p. 4013-4022, 2015.
POVH, J. A.; RIBEIRO, R. P.; LOPERA-BARRERO, N. M.; JACOMETO, C. B.; VARGAS, L.; GOMES, P. C.; LOPES, T. S. Microsatellite analysis of pacu broodstocks used in the stocking program of Paranapanema River, Brazil. Scientia Agricola, Piracicaba, v. 68, n. 3, p. 308313, 2011.

RAYMOND, M.; ROUSSET, F. An exact test for population differentiation. Evolution, New York, v. 49, n. 6, p. 1280-1283, 1995.

RODRIGUEZ-RODRIGUEZ, M. D. P.; LOPERABARRERO, N. M.; RIBEIRO, R. P.; POVH, J. A.; VARGAS, L.; SIROL, R. N.; JACOMETO, C. B. Diversidad genética de piracanjuba usada en programas de repoblación con marcadores microssatélites. Pesquisa Agropecuária Brasileira, Brasília, v. 45, n. 1, p. 56-63, 2010 .

SANTOS, M. C. F.; HRBEK, T.; FARIAS, I. P. Microsatellite markers for the tambaqui (Colossoma macropomum, Serrasalmidae, Characiformes), an economically important keystone species of the Amazon River floodplain. Molecular Ecology Resources, Oxford, v. 9, n. 3, p. 874-876, 2009.

THOMÉ-SOUZA, M. J. F.; RASEIRA, M. B.; RUFFINO, M. L.; SILVA, C. O.; BATISTA, V. S.; BARTHEM, R. B.; AMARAL, E. S. R. Estatística pesqueira do Amazonas e Pará - 2004. Manaus: IBAMA/ProVárzea, 2007. 74 p.

YEH, F. C.; BOYLE, T. Y. Z.; XIYAN, J. M. PopGene Version 131: Microsoft Window-based freeware for population genetic analysis. Alberta: University of Alberta and Center for International Forestry Research, 1999. 29 p.

WRIGHT, S. Evolution and genetics of populations. Chicago: University of Chicago Press, 1978. 580 p. 
